\title{
Water Diplomacy and Water sharing problem between Bangladesh and India: a Quest for Solution
}

\author{
Fahmida Aktar \\ Associate Professor, Department of Political Studies, Shahjalal University of Science and Technology, Sylhet, Bangladesh
}

\begin{abstract}
Water is an important resource for all time, healthiness, and development. However, one in three people worldwide doesn't have enough water to satisfy their daily needs. Consistent with the $U N$, in 2025 nearly 2 billion people will live in conditions of absolute water scarcity, and two-thirds of the planet in areas of water stress. Bangladesh and India share 54 rivers. But there has been only one water-sharing agreement on one river that is 'The Ganges Water Treaty-1996'. Without such agreement with Bangladesh, India began constructing dams or diverting water from many Tran's boundary rivers. The absence of such agreements could lead to complex water-sharing conflicts within the future and should have negative, socio-economic, and political implications for bilateral relations between the two countries. This paper discussed Water Diplomacy and Water sharing problems between Bangladesh and India employed a triangulation research method Also, explain different International Treaties and laws associated with water. Also, attempt to identify a standard solution and proposals for resolve water sharing problems between Bangladesh and India.
\end{abstract}

Keywords- Water Diplomacy, Water Sharing Problem, Water Scarcity, Bangladesh-India Relations.

\section{INTRODUCTION}

$\mathrm{W}$ ater politics may be a term to ask inters and intrastate relations, suffering from the supply of water and water resources. The substituted term for Water Politics is additionally called; Hydro politics around the world. ${ }^{1}$ Surface and underground water don't respect political boundaries. This suggests that states must cooperate to manage water (GWP Strategy 2009-2013). ${ }^{2}$ Transboundary water resources contribute to the economic, social, and environmental well-being of communities around the globe. Despite their interconnectivity (national, sectoral), challenges remain in efforts to integrate the management of water resources that are shared across national and international borders. ${ }^{3}$

In the case of Bangladesh, water insecurity is going to be the best threat or challenge with reference to ensuring national security as its vulnerabilities come from both internal and external sources. ${ }^{4}$ the gap between the supply and demand of water in Bangladesh is ever increasing. When the state will fail to supply it, this will cause intense unrest and social instability. During this regard, the Chairman of the National Disaster Management Advisory Council said, "Water availability in Bangladesh is around
90 billion cubic meters $(\mathrm{BCM})$ during the season against the demand of about 147 billion cubic meters, a shortage of nearly 40 percent, leading to a drought-like situation in large parts of the country". 5

Bangladesh and India share a complete of 54 rivers between them. Since 1972, water relation between the two countries has been works-in-progress with both parties attempting to realize equitable water sharing. Bangladesh and India signed the 'statute of the Joint Rivers Commission' on 17 March 1972 which governs all rivers common to both nations. While a treaty on the Ganges was signed in 1996. Since the settlement of the Ganges issue, the Teesta river has become a source of discord. People living within the Teesta basin face severe problems during the lean season. Bangladesh also feels insecure about India's River Linking Project and Tipaimukh Dam Project. This is often a matter of concern regarding the longer term of-Bangladesh- India watersharing negotiation. Thus, this research has important legal, policy, and theoretical implications.

\section{BACKGROUND}

The India-Bangladesh water-sharing conflict dates back to the first 1970s. Bangladesh shares fifty-four rivers with India, and as a lower riparian country, has no control over them. But there has been only one water-sharing agreement on one river that is 'The Ganges Water Treaty-1996'. The unilateral water diversion or withdrawal of water from Transboundary or International rivers has been the long-standing policy of India. Without an agreement with Bangladesh, it's began constructing dams or diverting water from many Transboundary rivers like Teesta, Gumti, Khowai, Dharla, Dudkumar, Monu, etc. India had reportedly blocked rivers such as Muhri, Chagalnaiya, Fulchari, Kachu, and many others that flow into Bangladesh from Tripura. ${ }^{6}$ Bangladesh relies heavily on the flow of three major rivers: the Ganga, Brahmaputra, and Meghna commonly mentioned as GangaBrahmaputra-Meghna Basin (GBM), and their numerous tributaries and distributaries to satisfy its water demands primarily for agricultural productions, and secondarily for industrial productions, ${ }^{7}$ India and Bangladesh have signed The Ganges Water Treaty on 12th December 1996 to work out the Ganges water-sharing arrangements between them, yet it's 
been acknowledged out that there's a stronger need for a few water agreements to sustain a co-operative bilateral relationship and joint efforts to sustainably utilize and share common water resources. The absence of such frameworks, within the future, could lead to complex water-sharing conflicts and should have negative, socio-economic, and political implications for bilateral relations between the two countries. $^{8}$

The existing policies aren't working for a scarcity of political and national consensus in both countries and for lack of regional cooperation. An alternative explanation is that there are other hidden reasons like poor water governance, water scarcity in countries, selective (regime-wise) foreign policy, and unwillingness to abide by the law of nations. ${ }^{9}$

This paper, explains Water Diplomacy, different International Treaties, and laws associated with water sharing problems and identify water-related conflicts between Bangladesh and India. Also, attempt to identify a common solution and recommendations.

\section{METHODOLOGY}

This research paper is essentially qualitative in nature which employed a triangulation research method and supported secondary data. Secondary sources are books, reports, published research studies, case studies, newspaper articles, seminar and conference papers, the publication of national and international journals, magazines, and documents available on the web, government policies, and plans. Apart from content analysis, conducted several in-depth interviews to achieve comprehensive insights into the subject, The interpretation of knowledge was administered keeping in mind the general perspective of the research study. Efforts were made to integrate the info collected from different sources.

\section{WATER DIPLOMACY}

Water management is a crucial point on the worldwide agenda within the twenty-first century. ${ }^{10}$ To enhance the effectiveness of water diplomacy, it's of utmost importance to spot the factors that influence cooperation; Water diplomacy supported a mutual gain's approach, may therefore play an increasingly important role in preventing, mitigating, and resolving the growing water conflicts. ${ }^{11}$ It could involve formal high-level diplomatic interactions between riparian states or relationship building through unofficial dialogues organized by civil society organizations. Key elements within these encounters include fact-finding and therefore the involvement of third parties because they support the dialogue on the idea of which commonality and shared understandings are -hopefullydeveloped. ${ }^{12}$

To improve the effectiveness of these measures, it's essential to spot the factors that influence water cooperation at different levels. The various tracks of diplomacy are often defined as:

- Track 1 (traditional official diplomacy): Dialogues or negotiation between officials, which mostly include politicians, policymakers, and high-ranking military personnel during a nation-state centered perspective. ${ }^{13}$

- Track 1.5: "Diplomatic initiatives that are facilitated by unofficial bodies, but directly involve officials from the conflict in question", 14

- Track 2: As defined by, "unofficial, informal interaction between members of adversary groups or nations, who can interact more freely than high-ranking officials, to develop strategies, to influence popular opinion, and organize human and material resources in ways in which might help resolve their conflict", 15

- Track 3: People-to-people or grassroots-level diplomacy undertaken by individuals, civil society, and personal groups to encourage interaction and understanding of communities' issues, and to get awareness for empowerment within these communities. ${ }^{16}$

While traditionally, diplomacy is defined as high-level interaction and dialogue between the nation-states, within the present context, the definition has been broadened to incorporate various other levels as well. ${ }^{17}$ Hence, within the transboundary context, Track 1.5 and Track 2 diplomacy have played a big role in several river basins in building, trust, and confidence of multiple stakeholders. Such efforts and progress being made outside of the government domain through informal diplomacy can play a significant role when governmental cooperation is a non-starter. ${ }^{18}$ However, cooperation achieved through such informal diplomacy has usually remained outside the scope of "transboundary cooperation", because this cooperation isn't directly associated with benefits from the water resources.

\section{INTERNATIONAL LAW}

International law is the set of rules that nation-states use to manage their relations. Nation-states accept a rather detailed governance structure as the price of belonging to the international community. States that refuse to do so are increasingly rare and are usually treated as pariahs. International law generally regarded as being based on the consent of the nation-states, its principal subjects. International treaties affect only those nation States that consent, or agree, to be legally bound by the written agreement. International law is formed usually when nationstates need to cooperate with other nation-states. This need to cooperate creates an incentive to comply with international law. However, conditions do change, which can lead to violations of international law. Law-breaking nation-States may attract diplomatic pressures, measures adopted by the U.N. Security Council, sanctions, countermeasures, and in extreme cases, military intervention, responses, some of which may themselves be unlawful. ${ }^{19}$

International water law, like international law in general, may take either of two general forms: treaty law or customary international law.

Three separate international agreements predominate the 1997 UN Watercourses ${ }^{20}$; the $1992 \mathrm{UN} \mathrm{ECE}{ }^{21}$; and the 1966 
Helsinki Rules on the Uses of the Waters of International Rivers.

\section{GENERAL RULES OF LAW CONCERNING THE USE OF INTERNATIONAL WATERCOURSES}

More than 400 treaties apply to various aspects or forms of transboundary water resources. $^{22}$ these international agreements provide operational frameworks for inter-State cooperation mostly involving States sharing the same watercourse or drainage basin. There are several rules of international law of a general and fundamental nature that govern the conduct of the nation-States in relation to international watercourses. The most basic of these are the following requirements:

1. A State that uses an international watercourse has a general duty to cooperate with the other States sharing the watercourse;

2. A State uses an international watercourse in a way that is equitable and reasonable vis-à-vis other States sharing the watercourse;

3. International watercourse States take all appropriate measures to prevent significant harm to the coriparian States; International watercourse States provide prior and timely notification to other international watercourse States concerning any new use or change in existing uses of an international watercourse that may adversely affect those other States, together with relevant technical information, and that it consult with another international watercourse States. There is probably also an emerging rule requiring the protection of the ecosystems of international watercourses. ${ }^{23}$

\section{THE INDO-BANGLADESH JOINT RIVERS COMMISSION}

After the creation of Bangladesh in 1971, the two countries resumed talks over sharing the Ganga, Teesta, and other rivers. In 1972, India and Bangladesh established the IndoBangladesh Joint Rivers Commission (JRC) with the aim of "working together for the benefit of the peoples of the two countries", but originally focused on the joint management of the Ganges river basin. As per Article 4 of the Statute of the JRC, the Commission has the following functions -

- To maintain liaison for maximizing the benefits from common river systems to both the countries;

- To formulate flood control plans and implementation of joint projects;

- To formulate proposals for flood warnings, flood forecasting, and cyclone warnings. 24

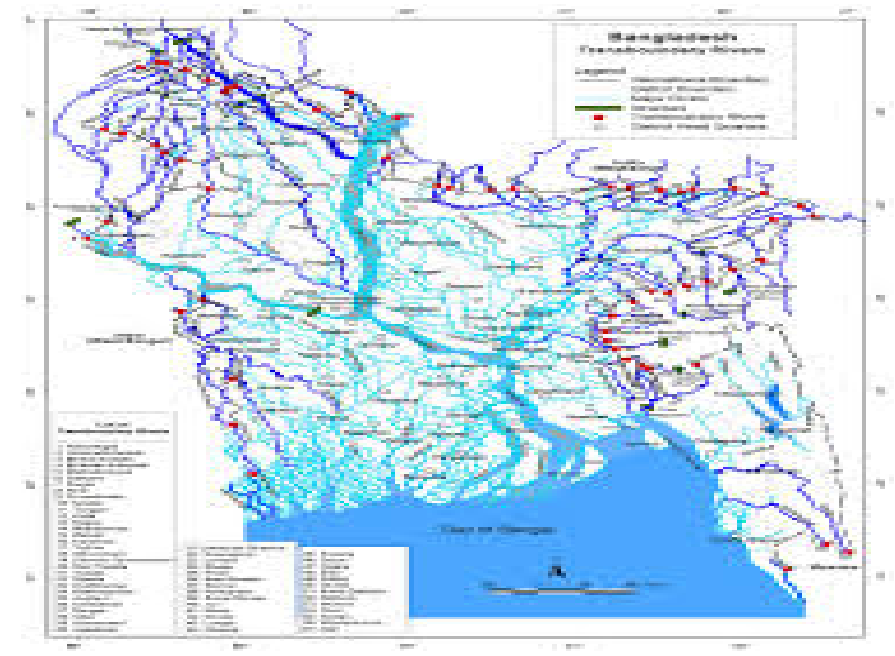

Fig 1: Tran's boundary rivers of Bangladesh

Source: Bangladesh, Joint River Commission (2019). Trans boundary Rivers of Bangladesh.http://www.jrcb.gov.bd/.

\section{THE GANGES WATER DISPUTE}

The Ganges water dispute dates back to 1951 when Bangladesh formed the Eastern Province of the Federation of Pakistan. India then planned to construct a barrage at Farakka, 18 kilometers upstream from Bangladesh; the approach was to grounds of preservation and maintenance of Calcutta port by improving the regime and navigability of the Bhagirathi Hooghly river system. The Indian plan included a 38-kilometer canal to require far away from the barrage so as to supplement the lean season flow of Bhagirathi Hooghly. ${ }^{25}$ Although the 1996 Ganges Water Treaty resolved the Farakka dispute, agreements on the sharing of other major rivers are yet to be concluded. The Ganges treaty has been criticized thanks to less effective during the lean period. It performs poorly within the most critical periods of March and April. ${ }^{26}$ The shortage of the article and therefore the lack of any guarantee clause made the treaty less effective. ${ }^{27}$ The dispute resolution mechanism of the Ganges treaty has been widely condemned. Additionally, certain activities like India's unilateral withdrawal of water from Farakka Barrage and Bangladesh's decision to boost the difficulty at the UNGA created trust deficit and diffidence. As a result, the Ganges Treaty lacks an arbitration and guarantee clause, but Article 9 of the Ganges Treaty specifies that the "principle of equality", shall guide the longer time activities of both nations. This is often the reflection of "equitable utilization theory", supported by Roman maxim "sic utere tuo ut alienum non laedas", which suggests "you use your own so as not to injure another". Articles 5-7 of UN Watercourses Convention 1997 and Articles 4-8 of the Helsinki Rules, 1966 also are supported the "equitable utilization theory" but India and Bangladesh aren't the signatories of the UN Watercourse Convention 1997. As such, they can't claim any legally binding effects for dispute settlement. ${ }^{28}$ The Ganges 
Treaty is meant to be reviewed every five years, but it's never happened though it's renewable with none.

\section{THE RIVER-LINKING PLAN}

The Indian plan of river linking has a world dimension because most of the Himalayan River originated beyond the boundary of India, and run through countries aside from India, both upstream and downstream. Bangladesh located downstream drains outflows of the string of mighty Himalayan Rivers to the Bay of Bengal. The plan of large huge scale water diversion under the river Interlinking plan has created serious concerns in Bangladesh.

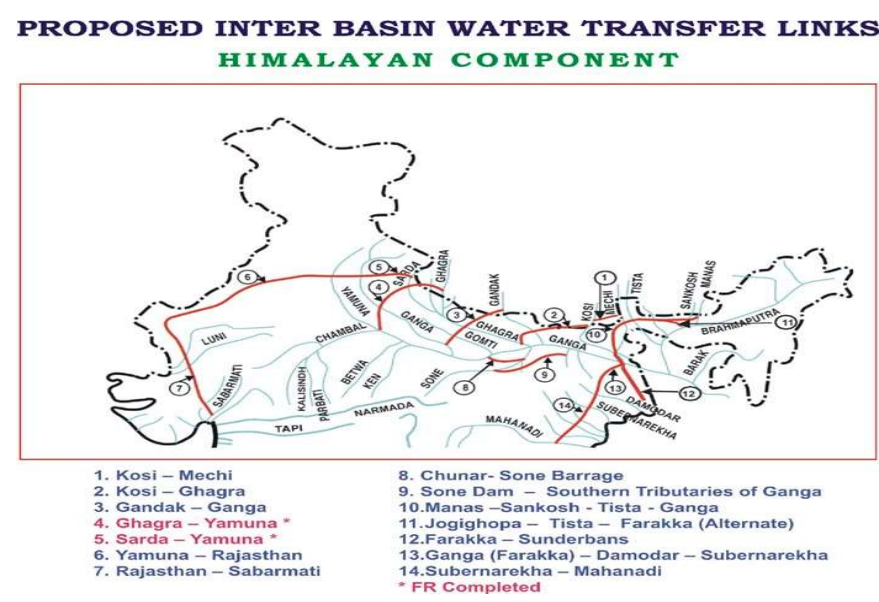

Fig 2: Inter Basin Water Transfer Link (Himalayan Component)

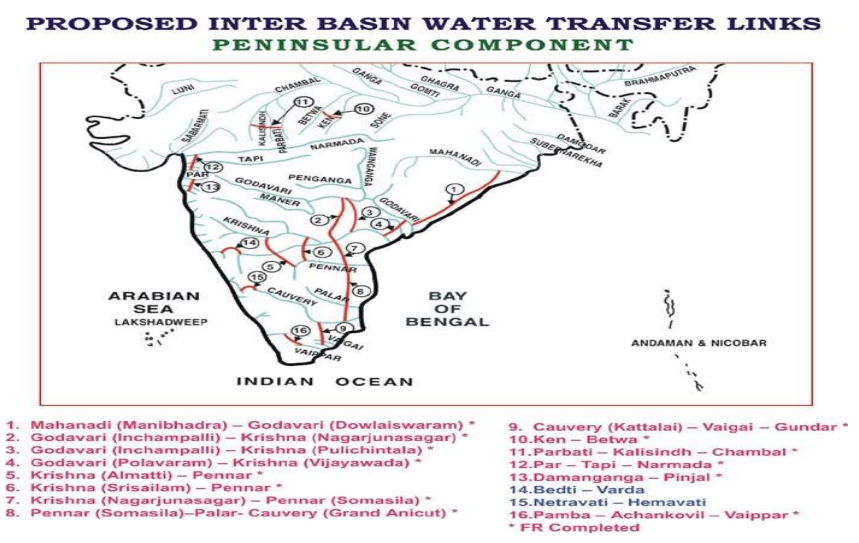

Fig 3: Inter Basin Water Transfer Link (Peninsular Component)

Source (Fig2 and Fig 3): India, Ministry of Water Resources. (1980). Inter Basin Water Transfer Links (Himalayan and Peninsular Component).http://mowr.gov.in/schemes-projectsprogrammes/schemes/interlinking-rivers.

The Indian river-linking project has three major componentsthe Himalayan rivers inter-link component, a southern peninsular component, and an intra-state river linking component. Thus far as literature goes, there are 14 inter-link projects under the Himalayan component, 16 project proposals under the peninsular component, and 36 projects under the intra-state component. Naturally, if the waters of those rivers are diverted upstream there'll be less flow and fewer water within the Jamuna, the Padma, and therefore the Brahmaputra in Bangladesh. ${ }^{29}$

\section{TEESTA RIVER}

India features a barrage on the Teesta at Gajaldoba at the Jalpaiguri district of West Bengal, a touch upstream of the point where the river enters Bangladesh. The Bangladesh government features a barrage at Doani within the Lalmonirhat district before the Teesta joins the Brahmaputra. In recent years, water volume within the Teesta has gone below the 100 cumec level in peak summer, April and May. Recognizing the shortage of adequate water within the Teesta, a committee of the West Bengal government under Indevar Pandey, the principal secretary of the general public work's department, has recently decided that the state will irrigate only 52,000 hectares with river's water, a reduction of $90 \%$ from the original plan. ${ }^{30}$

Teesta water negotiation started in 1951. At that period, Bangladesh was a part of Pakistan. After the independence of Bangladesh, the negotiation with India on Teesta water sharing officially began with the ad hoc agreement in July 1983. Consistent with the ad hoc agreement, Bangladesh was supposed to get 36 percent whereas India was supposed to get 39 percent of water. But the agreement wasn't implemented. After an extended period of disagreement, an interim watersharing agreement has been drafted in 2010 during the 37th meeting of the JRC. The draft specifies that Bangladesh and India would each get 40 percent of the particular flow available at Gazaldoba Barrage in West Bengal, while 20 percent of the particular flow available at Gazaldoba would be reserved as environmental flow. ${ }^{31}$

During former Indian Prime Minister Manmohan Singh's visit to Bangladesh in September 2011, the signing of the agreement on Teesta waters was one of the major objectives but the Chief Minister of West Bengal opposed the agreement. She stated that water was a state subject under the Indian Constitution, and therefore the state needed to give its consent to the central government prior to any agreement with Bangladesh. Thus, the draft Teesta treaty remained unsigned during that point. Prime Minister Sheikh Hasina's latest visit to India in April 2017 renewed the hope of signing the agreed Teesta agreement but this time, again, India refused to sign it. Chief Minister Mamata Banerjee proposed that Bangladesh should look for alternative sources of water aside from the Teesta. ${ }^{32}$ Prime Minister Sheikh Hasina visited India in October 2019. The difficult issue of sharing Teesta river water remained unsolved. In the joint statement, "Prime Minister Modi informed that his government is working with all stakeholders in India to conclude the agreement at the earliest." The biggest roadblock to Teesta is the opposition by West Bengal Chief Minister Mamata Banerjee. ${ }^{33}$ A Summit in the virtual form held. Both sides held comprehensive discussions on all aspects of bilateral relations and highlighted the need for early signing of an interim agreement for sharing 
of the Teesta waters. Modi reiterated India's sincere commitment and continued efforts of the Government of India in that regard.

Teesta's dry period starts in October and the monsoon starts in April-May. The crucial period within the Teesta is SeptemberOctober when supplementary irrigation is required in some areas of the river basin for agriculture. During the dry season, the Teesta gets around 6,000 cusecs of water but, Bangladesh needs 8,000 cusecs, and India needs 16,000 cusecs, so it is a difficult task to satisfy these demands. On the opposite hand, the Teesta overflows during the monsoon. Its water flow typically exceeds 300,000 , cusecs, to 450,000 cusecs. If governments come to the fore to develop an effective water management mechanism like building a reservoir upstream, then the surplus monsoon water is often shared during the dry period. So, consistent with experts, the Teesta treaty should have two mechanisms: ensuring water flow during the dry period and managing water for the remainder of the year within the entire river basin. Additionally, it should make sure the prevention of flood and river erosion during the monsoon period. $^{34}$

\section{THE TIPAIMUKH}

Currently, the Central Water Commission of India is getting to divert, control, and withdraw more and more water from those common rivers between Bangladesh and India. Barak River flows alteration and withdrawal by constructing a hydroelectric dam at Tipaimukh and Fulertal Barrage is one of those planning. The last havoc that Bangladesh can ever imagine is close to coming when it is being strongly believed that India is planning to divert the Brahmaputra flow to the water 'deficit' states of India. ${ }^{35}$

The Tipaimukh Dam on the Barak River is now neither an idea nor just a mere proposal of the Central Water Commission of India. It is very much on its way to be constructed with an aim to produce an estimated 1,500 MW electric power with the firm power generation of $401 \mathrm{MW} 1 .^{36}$

The dam would severely affect agriculture and fisheries, vegetation, and greenery, including local flora and fauna, and generate a huge displacement of individuals and livestock in Bangladesh. The consequences of the Dam are not only confined to Bangladesh because it also of serious consequences to the people of the Indian states of Manipur and Nagaland as the Barak-Surma-Kushiara is an international river. $^{37}$

The terrible potential outcomes to be faced by Bangladesh from the construction of the Dam have summarized in six broad categories: hydrology, flooding pattern, and riverfloodplain-wetland ecosystem, morphology, water quality, Dam collapse, and other general impacts. ${ }^{38}$ The proposed Dam site is found within the Zone of Seismic Zoning Map of India, which during 1953-92, this region had experienced twenty-one earthquake of quite $6.5^{\circ}$ on the Richter scale. ${ }^{39}$

\section{RECOMMENDATIONS}

Problematic situations among the neighboring states always create a crisis and play a crucial role within the state's political instability. These tense relationships also challenge regional stability. This is often a thing within the South Asian region where some states have boundary issues and a couple of have water issues. So on the lookout for higher liaison between Bangladesh and India, the next steps should be taken to make sure not only regional stability but the inside strength of the state:

\section{Sharing of Hydrological Data}

The sharing of hydrological data is widely considered a fundamental component of transboundary cooperative history because it is extremely important to support deciding and planning among riparian's. Thus, the shortage of accurate data and thus the sharing of data by creating power and knowledge asymmetry significantly hamper the negotiation process.

\section{The regular talks on the water sharing issue.}

According to the statute of the JRC, the ministerial-level meetings are imagined to hold fourfold during a year, but there are only 37 meetings since the inception of the JRC in 1972 . The 37 th meeting was held in 2010 . Then, there was no ministerial-level meeting that happened to settle issues concerning common rivers. So, there should be taking regular talks on the water sharing issue.

\section{Unique Political vision and policy on the Water issue}

Political vision and policy play a task in creating indolence within the negotiation process. The political vision determines whether the negotiations are going to be a hit or a failure. Thanks to the changed regime with different foreign policies and lack of political determination are major challenges of water negotiations in both countries (Bangladesh and India).

\section{Research on Transboundary Water Negotiations}

There is an honest number of state organizations like River Research Institute, Water Resources Planning Organization, Bangladesh water project Board, Bangladesh Haor and therefore the Wetland Development Board, Flood Forecasting and Warning Centre, and JRC. These organizations' only affect technical aspects. Even there's no research team within Bangladesh a part of JRC. On the opposite hand, water-related departments and research institutes publicly and private universities don't get enough funding for conducting research on transboundary water negotiations. Hence, compared to India, Bangladeshi researchers have a scarcity of contribution to shaping Bangladesh's water diplomacy. Smurti S. Pattnaik (Senior Research Fellow of IDSA, India) said that "with negotiation we (Bangladesh and India) can resolve all bilateral conflicting issues". 


\section{Water Expert Negotiator}

In Bangladesh, water experts remain frequently absent at the negotiation table. This is also a barrier because carrier diplomats are mostly unknown about the technical part of the water sharing process. Indian diplomats have moreupdated data, but still, their water experts cannot participate in Government-to-government negotiations on water sharing issues.

According to Hydrological expert Professor Dr. Ainoon Nishat, "The Joint River Commission was set up to discuss technical issues but now it has become a body where negotiations take place. Negotiations and decision making should be made at the political level, and technical people can be included there as advisers."

\section{Basin-wise river management}

The demand and availability of water vary within the upstream and downstream of a river. Usually, the water flow within the upstream surpasses the demand, while it's the other within the downstream. The optimum solution to balance the supply and demand could be creating proper modeling of the rivers based on water quantity and quality. This way, we can resolve issues like a flood, navigation, irrigation, hydropower, and fisheries for the entire basin of a particular river. All this is covered by basin-wise river management. Hydrological expert Professor Dr. Ainoon Nishat said, "I will push for basin-wide management of our joint rivers which is also the political instruction of the day. The river should be considered a celebration within the negotiation where we've to make the sure minimum environmental flow of the river."

\section{Track 2 Diplomacy}

Bangladesh must apply Track 2 Diplomacy in negotiating the water sharing issue. Currently, Bangladesh's water negotiation is predicated on applying track-1diplomacy. Besides applying track-1 diplomacy, the appliance of track-2 diplomacy could be an honest option for a proactive water negotiation to non-governmental, informal, and unofficial contacts and activities between private citizens or groups of people, intellectuals, water experts, academics from both countries are often involved in informal meetings to hunt a sustainable and amicable solution. Dr. Jasim Uddin(Senior Research Fellow of BIISS, Bangladesh) said, "Track 2 Diplomacy will help to resolve a bilateral conflict between Bangladesh and India".

\section{Para diplomacy}

Para diplomacy could be an honest option for resolving the water disputes between Bangladesh and India. In India, power equilibrium is clear in state-center relations. Since the independence of India, it's been following the federalstate system. Thus, the Delhi-centered negotiation process of Bangladesh might not be ready to produce the specified result.

\section{Integrative approach}

Bangladesh may specialize in an integrative approach to water negotiation. An Integrative approach in water negotiation emerges when a celebration recognizing that water isn't a hard and fast resource. supported this assumption, policymakers and diplomats believe improving the general efficiency of water use, which, in effect, can "create" more water. In an integrative approach, parties in negotiation consider multiple issues simultaneously as they will attempt to create value and maximize benefits by tradeoffs between them. In this respect, both countries can consider multiple issues just like the transit issue, trafficking, terrorism simultaneously with water negotiation.

\section{Multi-track water diplomacy}

Multi-track water diplomacy refers to effective water cooperation for maximizing mutual gains and achieving joint wins for all parties. This framework has great potential to create a sound bridge from the particular or potential conflict to effective cooperation and practical solutions. Thus, both Bangladesh and India may consider this approach to unravel the water-sharing problem.

\section{CONCLUSION}

We hope that the analysis and proposals during this paper are going to be considered in a positive way for locating the way forward in bilateral relations. There's tremendous goodwill and positive sentiment in India and Bangladesh towards one another. If recommendations of this paper are implemented, it'll be possible for the two countries to beat a number of the irritants and forge ahead on a collaborative path of peace and prosperity within the region. In summary, a successful negotiation requires an agreed platform. Once this example developed, both parties can calm down all the prevailing water sharing disputes.

\section{REFERENCES}

[1] Khalid, I. (2010). Bangladesh Water Concern, South Asian Studies, $25(1), 73-87$.

[2] West Africa. Global Water Partnarship (2009). Implementing the GWP Strategy 2009-2013 Report on the Global Water Partnership Consulting Partners Meeting. https://gwp.org/globalassets/global/about-gwp/strategicdocuments/gwp_cp_meeting_aug.

[3] Wouters, P. (2013). International Law-Facilitating Transboundary Water Cooperation. Elanders press.

[4] Islam, M. S. (2011 May 31). Water for Security and Development. The New Age.

[5] Islam, M. S. (2011June 28). Water Scarcity and Conflict: A Bangladesh perspective. The Daily Star. https://archive.thedailystar.net/forum/2011/june/water.htm.

[6] Islam, M. S. (2011 June 28). Ibid.

[7] Mohapatra, B. (2019, March 21-23). The International Conference on India-Bangladesh Trans-boundary Rivers: Management and Conflict over Water Resources in Ganga-Brahmaputra-Meghna River Basin. North-Eastern Hill University, Shillong, India.https://networks.h- 
net.org/node/73374/announcements/3702782/internationalconference-india-bangladesh-trans-boundary-rivers

[8] Ibid.

[9] Chan, N. W., Roy \& R. Chaffin, B. (2016). Water Governance in Bangladesh: An Evaluation of Institutional and Political Context. MDPI. 8 (9), 403. https://doi.org/10.3390/w8090403.

[10] United Nations. (2015). Sustainable Development. United Nations Headquarters.

[11] Pohl, B., Carius, A. \& Conca, K. (2014). The rise of hydrodiplomacy: strengthening foreign policy for transboundary waters. Adelphi Publications.

[12] Bokova, I. \& Ovink, H. (2016). The Multi-track Water Diplomacy Framework: A Legal and Political Economy Analysis for Advancing_Cooperation over Shared Water's. Institute for Global Justice.

[13] Barua, A.,Deka, A. \& Gulati, V. (2019). Re-Interpreting Cooperation in Transboundary Waters: Bringing Experiences from the Brahmaputra Basin. MDPI. 11(12), 2589. https://doi.org/10.3390/w11122589.

[14] Nan, A.S. (2005). Track One-and-a-half Diplomacy: Contributions to Georgia-South Ossetian Peacemaking. In Fisher, R.J., (Ed.), Paving the Way: Contributions of Interactive Conflict Resolution to Peacemaking, (pp. 161-173. Lexington Books.

[15] Montville, J.V. (1991). The Arrow and the Olive Branch: A Case for Track Two Diplomacy, In Volkan, V. D., Julius, D. A. \& Montville, J.V (Eds.), The Psychodynamics of International Relations (pp. 161-175). Lexington Books.

[16] Barua, A. (2018). Water diplomacy as an Approach to Regional Cooperation in South Asia: A Case from the Brahmaputra Basin. Journal of Hydrology. 567, 60-70.

[17] Wehrenfennig, D. (2008). Multi-Track Diplomacy and Human Security. Journal of Human Security, 7, 80-88.

[18] Barua, A. (2018) Op.cit.

[19] Paisley, R. K. (2018). International watercourses, international water law, and Central Asia. The Central Asian Journal of Water Research 4(2), 1-26.

[20] United Nations General Assembly. (1997). Convention on the Law of the Non-Navigational Uses of International Watercourses: resolution. United Nations Headquarters, New York.

[21] United Nations Treaty Collections. (1992). Environment: Convention on the Protection and Use of Transboundary Watercourses and International Lakes. United Nations Headquarters.

[22] Giordano, M. \& Wolf, A.T. (2013). The World's International Freshwater Agreements: Historical Developments and Future
Opportunities. United National Environment Programme. http://www. transboundarywaters. orst.

[23] Paisley, R. K. Op.cit.

[24] Parry, A.W. (2020). Teesta River Dispute between India and Bangladesh.INSAMER. https://insamer.com/rsm/icerik/dosya/dosya_2634.pdf.

[25] Swain, A. (1993). Conflicts Over Water-A Case Study of the Ganges Water Dispute, Security Dialogue 24 (4), 8.

[26] Ibid.

[27] Nishat, A. \& Islam, F. (2000). An Assessment of the Institutional Mechanisms for Water Negotiations in the Ganges-BrahmaputraMeghna System. International Negotiation, 30 (4), 292-295.

[28] Ibid

[29] Kolas, A., Barkved, L. J., \& Bhattacharjee, J. (2013). Water Scarcity in Bangladesh Transboundary Rivers, Conflict and Cooperation. Peace Research Institute.

[30] Chaudhary, J. (2014, November 20), India renews "disastrous" river linking project.The Third pole. https://www.thethirdpole.net/2014/11/20/india-river-linkingproject/.

[31] Basu, J. (2017, April 4). Teesta has one-sixteenth of water needed. The Third pole. https://www.thethirdpole.net/bn/2017/04/14/teesta-has-onesixteenth-of-water-needed/.

[32] India, Strategic Foresight Group (2013). Rivers of PeaceRestructuring India Bangladesh Relations. Strategic Foresight Group.

[33] Bhuiya, H.K. (2017, April 19). Dhaka Wants Signing of Agreed Draft, The Independent. https://www.theindependentbd.com/post/90767.

[34] Uddin, S.S. \& Sultana, S.T. (2017). Bangladesh-India Water Negotiations: Challenges and Way Forward. BIISS Journal, 38 (2), 93-118.

[35] Thakur, J. (2020). India-Bangladesh Trans-Boundary River Management: Understanding the Tipaimukh Dam Controversy 334.The ObserverResearch Foundation. www.orfonline.org/research/india.

[36] Khan, A. S., Masud, M. S. \& Palash, W. (2005). Hydrological Impact Study of the Tipaimukh Dam Project of India on Bangladesh. The Institute of Water Modeling (IWM).

[37] Islam, M. S. (2013). Development, power, and the environment: the neoliberal paradox in the age of vulnerability, Routledge.

[38] Khan, A. S., Masud, M. S. \& Palash, W. Op. cit.

[39] Arora, V. \& Ngamjahao, K. (2012). We can live without power, but we can't live without our land: indigenous hmar oppose the Tipaimukh Dam in Manipur. Sociological Bulletin 61(1), 109-128. 